\title{
Effects of physical disturbance on the cold-water megafaunal communities of the Faroe-Shetland Channel
}

\author{
Daniel O. B. Jones*, Ian R. Hudson, Brian J. Bett \\ DEEPSEAS Group, George Deacon Division, National Oceanography Centre, Southampton SO14 3ZH, UK
}

\begin{abstract}
The response of a deep, cold-water benthic community to physical disturbance from offshore drilling was investigated using Remotely Operated Vehicle (ROV) video in the Faroe-Shetland Channel. This study presents a novel method for characterising changes in the ecosystem function of deep-water benthic megafaunal communities in response to physical disturbance. Ecosystem function is investigated using a range of community parameters, particularly abundance and diversity. High levels of physical disturbance, characterised by smothering of the seabed within a radius of 50 to $120 \mathrm{~m}$ around the drilling site, resulted in significant but variable reductions in megafaunal abundance (up to $92.3 \%$ ). Reductions in diversity, particularly in species richness, were apparent between disturbed (Mao Tao estimated species richness of $\mathrm{ES}_{(500)}=12.9$ ) and undisturbed areas $\left(\mathrm{ES}_{(500)}=20.6\right)$. The implications of selective removal of taxa on ecosystem function and recovery are discussed. Low level disturbance had comparatively little effect on the megafaunal communities; the effects varied in nature depending on motility and functional group (e.g. motile scavenger abundances were maximal at intermediate distances from disturbance). We conclude by comparing the functioning of the ecosystem under different regimes of disturbance and discuss implications for recovery of disturbed deep-sea habitats.
\end{abstract}

KEY WORDS: Benthos - Disturbance - Megafauna - ROV imaging - Abundance - Diversity · Ecosystem function $\cdot$ Faroe-Shetland Channel

Resale or republication not permitted without written consent of the publisher

\section{INTRODUCTION}

The link between diversity and ecosystem function in marine systems is complex and, while specific relationships are difficult to define, it is generally agreed that there is a positive relationship between diversity and ecosystem function (Emmerson et al. 2001, Hughes \& Petchey 2001, Loreau et al. 2002). Ecosystem function has been measured as a considerable number of variables and investigated using a large array of experimental approaches (Loreau et al. 2002). Direct experimentation, as used in terrestrial and shallowwater systems, is difficult to implement in practice in the deep sea, but the nature of megafaunal communities allows remote quantification of community parameters such as diversity and abundance, with accu- racy, over relatively wide areas, through the use of imaging technology, e.g. Remotely Operated Vehicles (ROV) (Starmans et al. 1999). Community parameters, such as abundance and diversity, are frequently measured as indicators of ecosystem wellbeing (Magurran 2003) and can be used as a proxy for ecosystem function in studies of the effects of disturbance on biological systems. The rate of local extinction of species with disturbance may be greater in organisms of larger size (Solan et al. 2004), emphasising the importance of monitoring the diversity of megafauna.

Megafauna play an important role in benthic systems, particularly in arctic waters (Piepenburg et al. 1996), contributing significantly to benthic biomass (Schwinghamer 1981, Christiansen \& Thiel 1992), organic matter recycling (Smith et al. 1993) and total 
benthic energy turnover (Walker et al. 1987). Megafauna have an important role in ecosystem function, particularly in dispersing and redistributing organic matter and sediment (Smith et al. 1993) important in the recovery of benthic systems from disturbance (Romero-Wetzel \& Gerlach 1991). Quantitative understanding of megafaunal abundances and spatial pattern is important in assessing ecosystem effects and resilience to/recovery from physical anthropogenic disturbance, an impact that is becoming more widespread in the deep sea (Bluhm 2001). Seabed imaging highlights ecological pattern and structure in deepwater benthic systems, allowing a detailed assessment of the ecosystem that is not possible with traditional trawl or grab studies (Solan et al. 2002). Video allows focus on patterns within megafaunal species assemblages at scales relevant to community pattern and the areal extent of disturbance without introducing additional disturbance through the act of physical sampling. The real time observation and manipulation capability of ROVs is important for detailed study and collection of voucher specimens, permitting identification of species that may not be possible, and is often limiting, in other photographic studies (Solan et al. 2002).

The benthic communities of the Faroe-Shetland Channel experience anthropogenic disturbance primarily from trawl fishing (Bullough et al. 1998) and increasingly from the activities of the oil and gas industry (Davies \& Kingston 1992, Olsgard \& Gray 1995). Disturbance is important in natural benthic communities as a source of temporal and spatial heterogeneity (Sousa 1984) that may act to maintain species diversity (Dayton \& Hessler 1972). Diversity is maintained by preventing competitive exclusion by dominant species in an assemblage and, particularly in the deep sea, by providing increased habitat diversity and niche availability (Connell 1978). As the magnitude of disturbance further increases, diversity may be reduced as physical stresses reach levels that exclude many species. Anthropogenic disturbance is often sufficient to cause some loss of diversity in marine systems, particularly in the deep sea (Bluhm et al. 1995, Borowski \& Thiel 1998). As the oil industry expands to deeper waters in the Faroe-Shetland Channel, it is important to characterise and understand the natural communities and detect reliably the effects anthropogenic disturbance is having on community ecology (Underwood 1994). There is also a need for ecological research to become more concerned with problems of anthropogenic influence on natural systems at spatial and temporal scales of relevance to the organisms and habitats affected.

The main objectives of this study are to determine: (1) the effects of physical anthropogenic disturbance on megafaunal ecosystem functioning in a deep-water area, and (2) aspects of the ecology of megafaunal communities in the cold waters of the Faroe-Shetland Channel that aid understanding of the effects of present and future disturbance.

\section{MATERIALS AND METHODS}

Study area. The West of Shetland hydrocarbon fields are located on the southern flank of the Faroe-Shetland channel (Fig. 1). This area supports a high diversity of deep-water habitats and fauna which have been reviewed for the majority of the Faroe-Shetland Channel in the UK Atlantic Margin Environmental Survey (Bett 2001). The Faroe-Shetland Channel harbours a wide variety of megafaunal species, but, despite the long duration of study in this area (Thomson 1873), there have been relatively few detailed studies on the megafauna. This is especially true for the megafaunal communities living in the cold, arctic water in the deeper areas (>600 m) of the channel (Bett 2001). From what is known, the abundance of hard substratum (iceberg-rafted drop stones) leads to a well-developed encrusting epifauna with crustaceans and echinoderms being important faunal components on softer substrata (Bett 2001).

The Faroe-Shetland Channel is an important area for exchange of water between the Arctic and Atlantic oceans with warm Atlantic water $\left(>8^{\circ} \mathrm{C}\right)$ overlaying cold, subzero temperature, Norwegian Sea Deep Water $\left(2\right.$ to $\left.-1^{\circ} \mathrm{C}\right)$ (Turrell et al. 1999). The location of

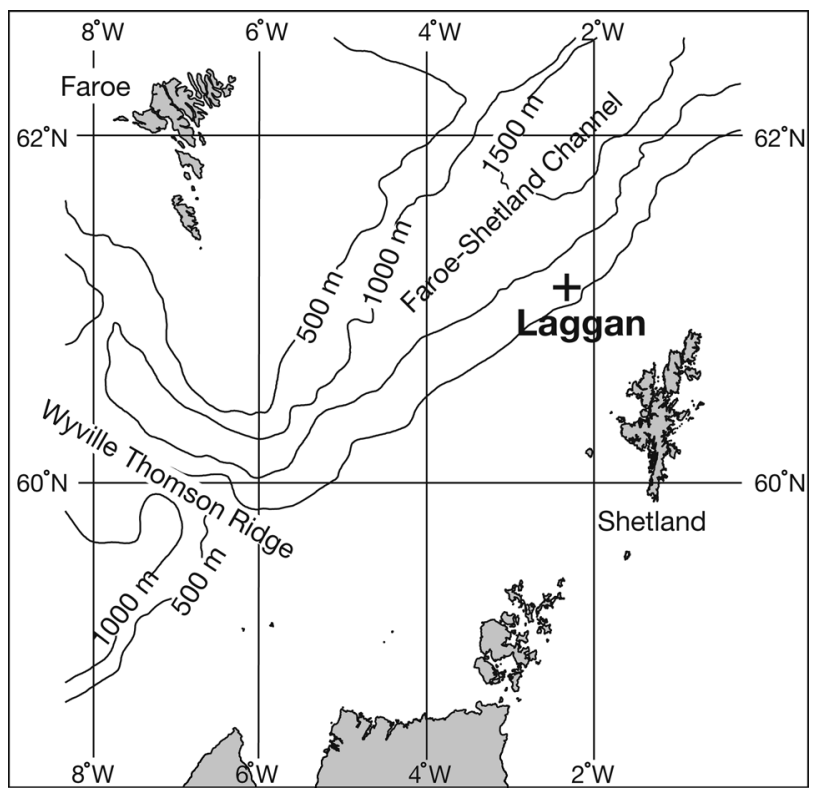

Fig. 1. Location of the Laggan study site in the Faroe-Shetland Channel 
the thermocline is dynamic and may occur between 400 and $600 \mathrm{~m}$ depth (Bett 2001). The benthic ecology of the Faroe-Shetland Channel is dominated by changes in hydrography as well as depth and sedimentary properties. Macrofaunal diversity is shown to be strongly linked with hydrography, with a diversity maximum at the boundary between warm and cold waters and declining diversity with greater depth (Bett 2001, Narayanaswamy et al. 2005).

At the Laggan study site (Fig. 1), the benthic fauna experience low water temperatures (measured by ROV temperature probe as -1 to $2^{\circ} \mathrm{C}$ over the $7 \mathrm{~d}$ prior to the present study), moderate currents (ca. $0.25 \mathrm{~m} \mathrm{~s}^{-1}$, estimated from ROV footage) predominantly to the northeast and strong enough to form mobile bedforms (sand ripples, $150 \mathrm{~mm}$ wavelength, indicating currents up to $0.6 \mathrm{~m} \mathrm{~s}^{-1}$ ) in the newly deposited drill spoil (Stride 1982). Acoustic Doppler current profiler (ADCP) data (Fig. 2) from a depth of $494 \mathrm{~m}$ revealed a complex pattern. Tidal cycles (semi-diurnal and spring/neap) are evident as is the near-consistent flow to the northeast; this is likely to be Norwegian Sea Arctic Intermediate water, with temperatures of 2 to $0^{\circ} \mathrm{C}$ (Turrell et al. 1999). There is also a short period (centred 10 April 2004) of southwesterly flow which, with temperature observations of $-1^{\circ} \mathrm{C}$, indicates the presence of FaroeShetland Channel Bottom Water (Turrell et al. 1999). The residual current observed (38 d record) had a flow direction of $040^{\circ}$ and an average speed of $0.16 \mathrm{~cm} \mathrm{~s}^{-1}$.

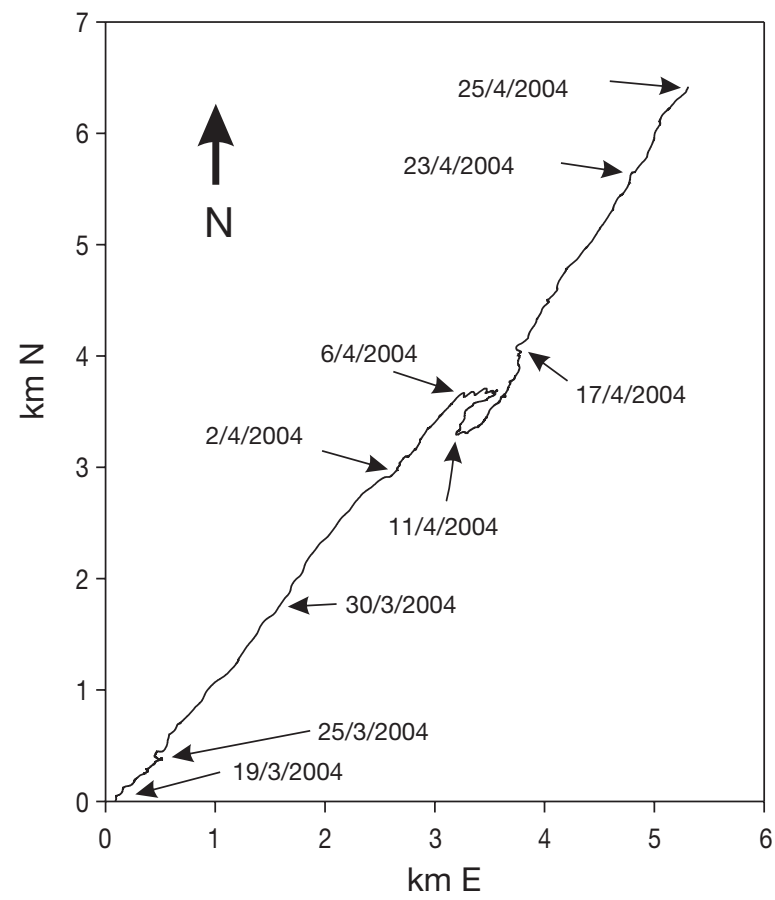

Fig. 2. Acoustic Doppler current profiler (ADCP) progressive vector plot, $494 \mathrm{~m}$ water depth at Laggan site. Data courtesy of Fugro. Dates given as d/mo/yr
The present investigations were carried out on board the semi-submersible drilling platform 'Jack Bates' (600 m water depth, $60^{\circ} 56.72^{\prime} \mathrm{N}, 02^{\circ} 53.48^{\prime} \mathrm{W}$ ) between 14 and 23 April 2004 at the Laggan field. The disturbance investigated was the top-hole drilling for a hydrocarbon exploration well (drilling commenced 25 March 2004; seabed disturbance duration was approximately $24 \mathrm{~h}$ ).

For the purposes of this study, the seabed around the source of disturbance was divided into $50 \mathrm{~m}$ zones radiating from the blow out preventer (BOP), a structure on top of the well, put in place after the initial drilling disturbance was caused. The distance of the ROV from the BOP was measured using sonar fixes on a clear sonar target. The extent of drill cuttings was characterised as follows: 'complete cuttings' (>95\% cuttings coverage), 'visible cuttings' (where patches of cuttings were visible on ROV video) and 'no cuttings' (where no cuttings could be seen on the ROV video). Graduated poles were placed on the seabed before drilling to assess spoil depth. The seabed drilling activity provided the indicator for physical disturbance examined in this study.

Data collection. Data were collected using an industry-operated work-class Clansman ROV (as part of the SERPENT collaborative project; www.serpentproject. com) equipped with a colour video camera (Remote Ocean Systems) and digital still camera (Kongsberg OE14-208), flash (Kongsberg OE11-242) and Sonar (Tritech). Cameras were mounted on a pan and tilt unit at the front of the ROV, which enabled oblique video to be taken. Before each transect the video was zoomed out to maximum extent and the camera was set to its most vertical angle ( $47^{\circ}$ below the horizontal). A total of 18 video transects were conducted radiating from the BOP (Fig. 3); the ROV was run in a straight line on a set bearing at a constant speed $\left(0.3 \mathrm{~m} \mathrm{~s}^{-1}\right)$ and altitude $(0.2 \mathrm{~m})$. Transects were typically $250 \mathrm{~m}$ in length, the maximum extension of the ROV's tether. Transect width $(0.91 \mathrm{~m})$ was calculated from the camera acceptance angles $(\theta=$ horizontal angle, $\omega=$ vertical angle), the angle of the camera from vertical $(\delta)$ and vehicle altitude (a):

$$
\text { width }=2 \sin (0.5 \theta) \sqrt{a \sin (90-\delta-0.5 \omega)^{2}+a^{2}}
$$

Transect width was also verified by passing over objects of known size on the seafloor. The optical resolution of the cameras permitted all organisms larger than $5 \mathrm{~cm}$ to be reliably identified. In addition to transects, ROV suction sampling, detailed inspection and still photography of selected individual organisms were used to aid species identification.

Pre-drilling qualitative video surveys of the immediate area around the drill site had previously been 


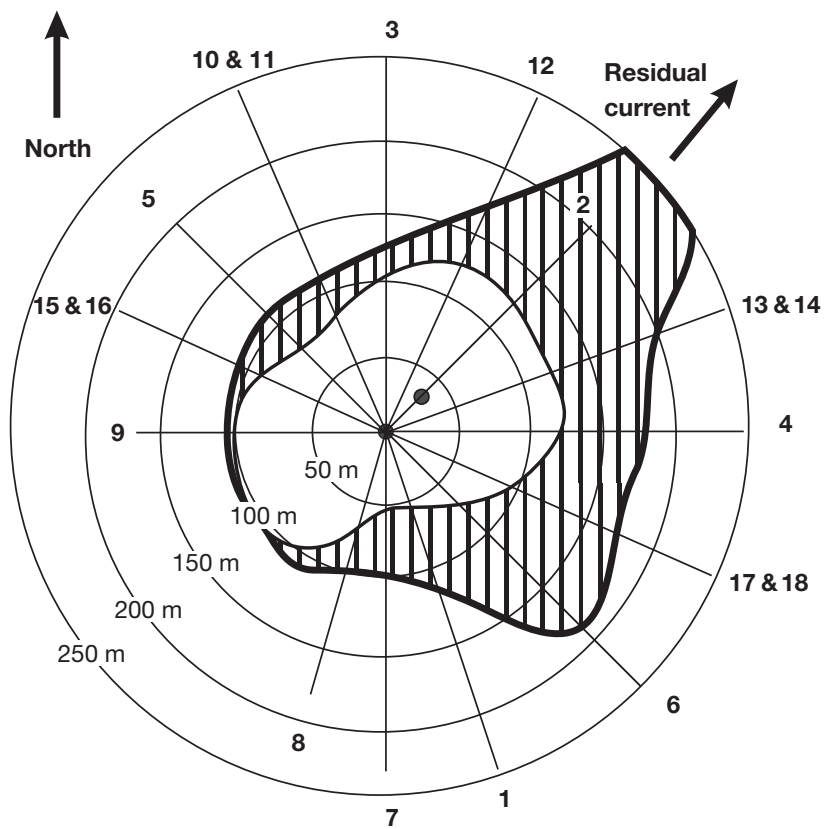

Fig. 3. Remotely Operated Vehicle (ROV) transects (1-18) conducted around the Laggan site, showing the extent of complete (central white area) and partial (hatched area) physical disturbance of the seabed, and $50 \mathrm{~m}$ zones radiating from the disturbance source. Filled circles represent drilling locations

undertaken to ascertain the general nature of the seabed and megafaunal community prior to disturbance by drilling.

Data analysis. Video transects were replayed at half speed and all visible organisms were counted along the entire transect. Colonial organisms were counted as single individuals. Infaunal species, when seen, were counted if enough of their body was visible for identification. Only benthic fish were counted, i.e. those fish that dwell on and feed at the seabed. Abundances were then standardised to numbers $\mathrm{ha}^{-1}$.

Two separate classification schemes were adopted, distance from point source of disturbance and visible seabed disturbance. (1) Distance was used as a proxy for intensity of initial disturbance, which is assumed to occur approximately symmetrically around the source of disturbance. Initial disturbance is thought to result in very high sediment deposition rates and turbidity. (2) Visible seabed disturbance reflects the actual situation present at Laggan. It is different from the initial impact as a result of longer-term redeposition of material in predominant currents; visible seabed disturbance represents the more sustained effects of disturbance through smothering. For analysis by distance from disturbance, each transect was partitioned into $50 \mathrm{~m}$ lengths. For analysis by visible disturbance categories, each transect was partitioned into 3 visible disturbance categories (complete, visible and no cuttings); numbers were standardised to densities as partitions were not of equal length. For both analyses, within each partition, counts from 3 randomly chosen transects were pooled to form each sampling unit (resulting in 27 sampling units for distance and 18 for visible disturbance).

Megafauna were divided with respect to motility into mobile and sessile taxa. Fauna were also divided by predominant feeding mode into sestonivores (filter and suspension feeders), deposit feeders and predators/scavengers.

A range of univariate diversity indices were calculated to assess both the dominance and species richness aspects of diversity (Gotelli \& Colwell 2001, Magurran 2003). These measures were principally calculated using PRIMER (see below), the Berger-Parker index calculated by spreadsheet, and sample based species density rarefaction implemented using 'EstimateS' software (Colwell et al. 2004).

Community analysis is based on densities of all taxa, a square root transformation was applied to buffer the influence of domianant taxa (Clarke \& Warwick 2001). Similarities were calculated using Bray-Curtis coefficients (Clarke \& Warwick 2001). The similarity values were subjected to both classification (hierarchical group-average clustering) and ordination (nonmetric multi-dimensional scaling) using the software PRIMER (Clarke \& Warwick 2001). Other PRIMER routines (e.g. analysis of similarities [ANOSIM] and multivariate dispersion [MVDISP]) were also used to further examine the results of the community analyses (Clarke \& Warwick 2001).

\section{RESULTS}

Analysis of ROV video footage revealed a total of 2135 megabenthic organisms from 27 nominal taxa (Table 1) in a total area surveyed of $3767 \mathrm{~m}^{2}$. Arthropods (39\% megafauna, up to $4786 \mathrm{ha}^{-1}$ ) were predominantly Pandalus borealis, although this group included hermit crabs, tube-dwelling amphipods and Colossendeis sp. pycnogonids. Porifera (34\% total megafauna, up to $3797 \mathrm{ha}^{-1}$ ) were grouped morphologically into taxa but could not be identified further. Echinoderms (23\% total megafauna, up to $2418 \mathrm{ha}^{-1}$ ) were dominated by the urchin Echinus elegans, and asteroids Ceramaster granularis granularis and Henricia pertusa, although other asteroids, ophiuroids and comatulid crinoids were also present. The ophiuroid Ophiactis abyssicola was very common $\left(\sim 100 \mathrm{~m}^{-2}\right)$, as seen in high resolution still photographs and suction samples, although it was too small to be identified from the transect survey video footage. The remainder of the megabenthos ( $4 \%$ ) comprised molluscs, cnidarians (actiniarians and alcyonarians) and benthic fish. 
Table 1. Abundance and composition of megafaunal communities around the Laggan site, tabulated by distance from disturbance source, and by level of disturbance (full: total seabed smothering; partial: disturbance visible on seabed; none: no visible disturbance to seabed). indet: indeterminate. Additional species observed (with group in parentheses)

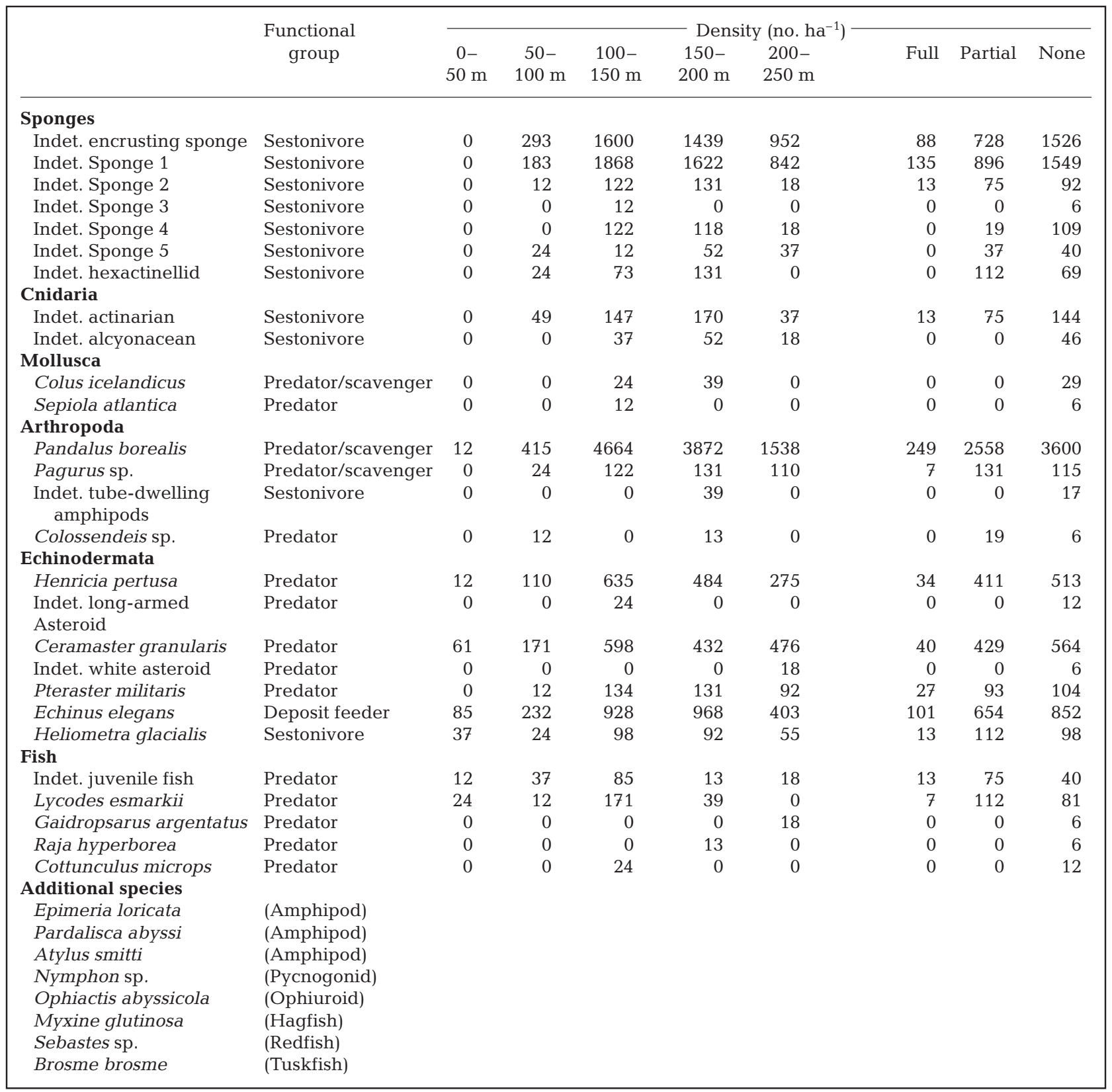

Prior to disturbance and beyond the disturbed area there was a highly heterogeneous distribution of benthic megafauna. The distribution of megafauna in these 'natural' seabed areas was primarily driven by substratum type and the availability of suitable microhabitats. The stochastic arrangement of icerafted cobbles and boulders are important in determining the small-scale distribution of the megabenthos. Most sessile filter feeders were attached to hard substrata; many of the echinoderms preferred softer sediments, being more common in gravel and sand areas.

Physical disturbance from drilling resulted in local scale $(<100 \mathrm{~m})$ smothering of the benthos, particularly in the direction of the residual current (Fig. 3). The disturbed area, with complete smothering $\left(\sim 28400 \mathrm{~m}^{2}\right)$ was larger than typical as a result of repeated drilling. The seabed was smothered to a maximum depth of $1 \mathrm{~m}$, although typically a lesser thickness. Disturbance was visible over a wider area $\left(>66800 \mathrm{~m}^{2}\right)$ where 
disturbed sediment had collected in depressions and in the lee of ice-rafted boulders. Outside this area the seabed appeared to be unaltered when compared to pre-disturbance ROV footage from the study site; seabed images suggest that it consisted of a heterogeneous mix of sand, gravel and occasionally cobbles and boulders.

Complete seabed disturbance resulted in low total megafaunal abundance with typically only small numbers of errant benthic megafauna. Larger boulders occasionally protruded above the level of smothering, acting as islands of megafaunal abundance; these boulders account for almost all observed benthic megafauna in the complete spoil areas. The seabed drilling structure did not appear to attract large numbers of fish as seen in other West of Shetland locations (authors' pers. obs.), although eelpouts Lycodes esmarkii were observed sheltering beneath it. Total megafauna abundance was significantly different between disturbance regimes (Kruskal-Wallis, $H=25.31$, df $=3,17 \mathrm{p}<0.001$ ), being higher in partially disturbed areas than those with full disturbance (Mood's median test $\chi^{2}=5.33, \mathrm{p}<0.05$ ), although there were no significant differences in abundance between partially disturbed areas and those with no disturbance (Mood's median $\chi^{2}=1.33, \mathrm{p}=0.25$ ). Total abundance was very low near the source of disturbance ( 0 to $50 \mathrm{~m}$ zone; Table 2 ), it was highest at intermediate distances from the source of disturbance (11 514 ind. ha ${ }^{-1}$ at 100 to $150 \mathrm{~m}$ ) and reduced somewhat with further increasing distance (Fig. 4).

Univariate diversity indices (Table 2) indicated depressed megafaunal diversity in both the $50 \mathrm{~m}$ zone and the complete disturbance zone (Fig. 3), with further reaching effects noted for rarer species (type I indices). Shannon-Wiener diversity $\left(H^{\prime}\right)$ is significantly different between distance zones (Kruskal-Wallis $H=11.24, \mathrm{df}=4$, $26, \mathrm{p}<0.05$ ); it was very low 0 to $50 \mathrm{~m}$ from disturbance,

Table 2. Variations in megafaunal species diversity measures around the Laggan site, tabulated by distance from disturbance source, and level of disturbance. Density data are mean \pm SD. B-P: Berger-Parker index; SI: Simpson's index $\left(1-l^{\prime}\right)_{i} H^{\prime}$, Shannon-Wiener index $\left(\log _{\mathrm{e}}\right)_{i} \mathrm{ES}_{(\mathrm{n})}$ : rarefied species richness; $\mathrm{S}$ : species present; $\mathrm{ES}_{(\mathrm{area})}$ : Mao Tao estimate of species density

\begin{tabular}{|c|c|c|c|c|c|c|c|}
\hline & Density (ind. ha ${ }^{-1}$ ) & B-P & SI & $H^{\prime}$ & $\mathrm{ES}_{(\mathrm{n})}$ & $\mathrm{S}$ & $\mathrm{ES}_{\text {(area) }}$ \\
\hline \multicolumn{5}{|c|}{ Distance from disturbance source (m) } & $\mathrm{ES}_{(240)}$ & & $\mathrm{ES}_{\left(410 \mathrm{~m}^{2}\right)}$ \\
\hline $0-50$ & $244 \pm 225$ & 0.35 & 0.78 & 1.68 & 7.00 & 7 & 5.06 \\
\hline $50-100$ & $1636 \pm 863$ & 0.25 & 0.85 & 2.18 & 15.32 & 16 & 11.92 \\
\hline $100-150$ & $11514 \pm 4226$ & 0.41 & 0.78 & 1.95 & 16.54 & 22 & 18.94 \\
\hline $150-200$ & $9982 \pm 4094$ & 0.39 & 0.79 & 1.99 & 16.77 & 21 & 18.73 \\
\hline $200-250$ & $4927 \pm 4794$ & 0.31 & 0.82 & 1.98 & 14.15 & 17 & 16.94 \\
\hline \multicolumn{5}{|c|}{ Level of disturbance } & $\mathrm{ES}_{(500)}$ & & $\mathrm{ES}_{\left(545 \mathrm{~m}^{2}\right)}$ \\
\hline Complete & $740 \pm 1434$ & 0.34 & 0.78 & 1.85 & 12.91 & 13 & 21.73 \\
\hline Partial & $6536 \pm 5640$ & 0.39 & 0.82 & 2.12 & 16.75 & 17 & 17.13 \\
\hline None & $9647 \pm 3648$ & 0.37 & 0.81 & 2.06 & 20.61 & 27 & 5.83 \\
\hline
\end{tabular}

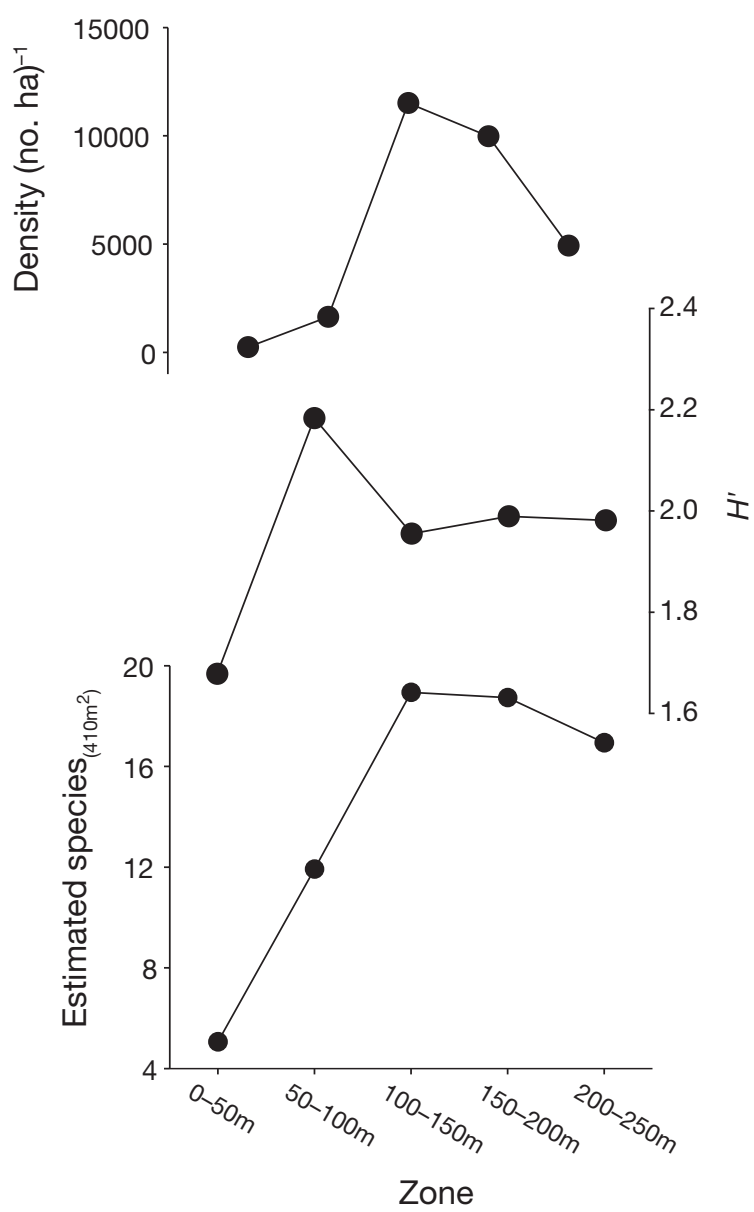

Fig. 4. Variations in faunal density and diversity $\left(H^{\prime}\right.$, Shannon-Wiener Index; $\mathrm{ES}_{(\text {area) }}$ Mao Tao estimate of species density) around the Laggan site with distance from source of disturbance

elevated in the 50 to $100 \mathrm{~m}$ zone (Table 2, Fig. 4) and slightly lower beyond $100 \mathrm{~m}$. Estimated species density (Fig. 4) increased from very low values near the source of disturbance to maximal levels at intermediate distances, slightly declining with increased distance. The fauna in both the completely disturbed and 0 to $50 \mathrm{~m}$ zone formed a distinct grouping on the Multi-Dimensional Scaling (MDS) ordination, with low similarities with the less disturbed areas $(26.0 \%$ for 0 to $50 \mathrm{~m}_{;} 48.6 \%$ for complete disturbance; Fig. 5A). ANOSIM indicated significant $(p<0.05)$ differences in megafaunal community composition between the 0 to $50 \mathrm{~m}$ zone, the completely disturbed area and all other zones (Table 3).

The megafaunal communities in partially disturbed areas were not distinct from those with no disturbance (Table 3). The benthic community in 
the area with no visible disturbance was quite homogeneous in composition, i.e. the undisturbed sample units formed a very tight group in the MDS plot (Fig. 5A: MVDISP = 0.41), whereas more scatter is evident in those from disturbed areas (Fig. 5A; MVDISP: partial disturbance $=0.99$, full disturbance $=1.59$ ) . Megafaunal community composition becomes more
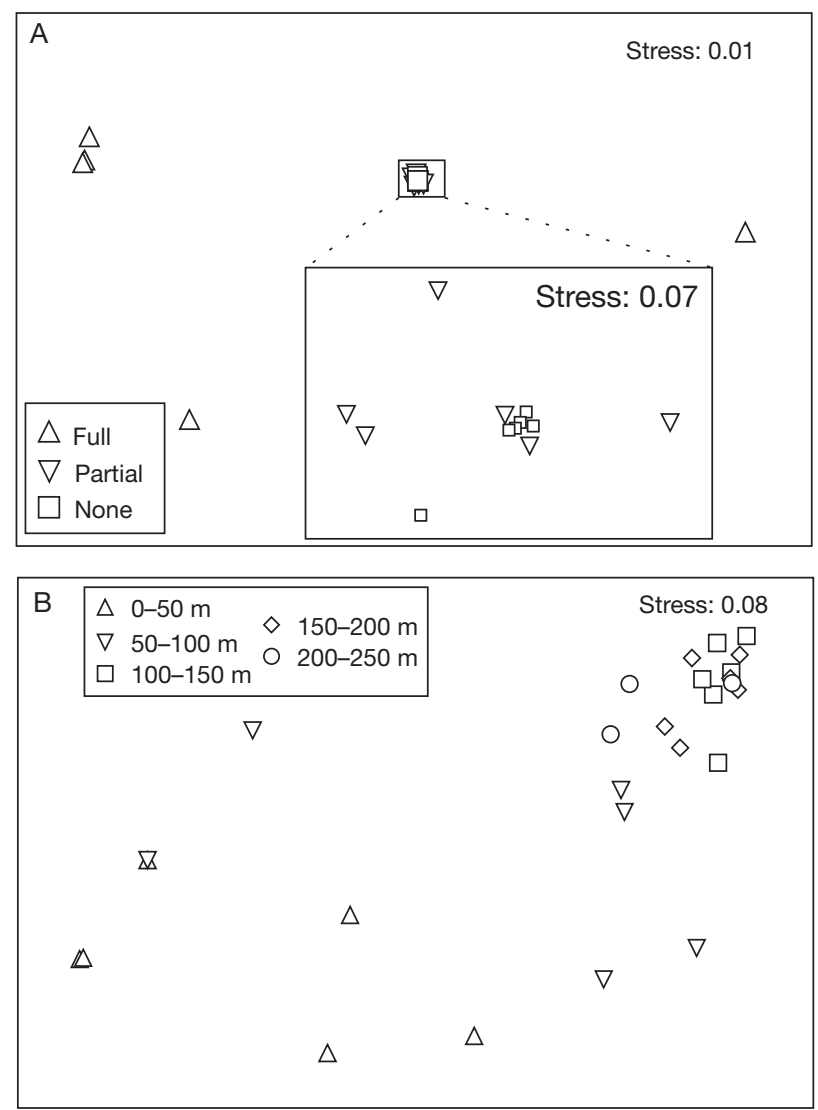

Fig. 5. Non-metric multi-dimensional scaling (MDS) ordination of the megafaunal communities around the Laggan site assessed (A) by level of disturbance, and (B) by distance from disturbance source

Table 3. Tabulation of PRIMER ANOSIM R-statistics from tests of variation in megafaunal community composition around the Laggan site, by (A) distance from disturbance source, and (B) level of disturbance (ns: $p>0.05$; ${ }^{*} p<0.05$; $\left.{ }^{* *} \mathrm{p}<0.001\right)$

\begin{tabular}{|lcccc|}
\hline A & $50-100 \mathrm{~m}$ & $100-150 \mathrm{~m}$ & $150-200 \mathrm{~m}$ & $200-250 \mathrm{~m}$ \\
\hline $0-50 \mathrm{~m}$ & $0.342^{*}$ & $0.987^{* *}$ & $0.985^{* *}$ & $0.932^{*}$ \\
$50-100 \mathrm{~m}$ & - & $0.544^{* *}$ & $0.483^{* *}$ & $\mathrm{~ns}$ \\
$100-150 \mathrm{~m}$ & - & - & $\mathrm{ns}$ & $\mathrm{ns}$ \\
$150-200 \mathrm{~m}$ & - & - & $\mathrm{ns}$ \\
B & & Partial disturbance & No disturbance \\
\hline Complete disturbance & $0.328^{*}$ & $\begin{array}{c}0.391^{*} \\
\mathrm{~ns}\end{array}$ \\
Partial disturbance & - & \multicolumn{4}{c}{} \\
\hline
\end{tabular}

consistent with distance from the disturbance source (Fig. 5B). ANOSIM reveals a distinct fauna in the areas $>100 \mathrm{~m}$ away from the disturbance source with significant differences from closer, more disturbed areas (Table 3). This trend is clear from the MDS plot (Fig. 5B) with a distinct grouping of comparatively 'undisturbed' sites (65.0\% similarity; mean MVDISP = $0.66)$, as distinct from the diffuse spread of the 'disturbed' sites (mean MVDISP = 1.45).

Mobile megafaunal density was higher than sessile in all disturbance regimes. The total abundance of sessile fauna increased with reduced disturbance, motile fauna had highest abundance at intermediate disturbance. The proportion of motile to sessile forms is broadly similar except in the partial disturbance zone where there is a higher proportion of mobile fauna (Fig. 6A). The total abundance of sessile and motile forms increased with distance from the source of disturbance, peaking at intermediate values, but the proportional abundance remained broadly similar except close to the source of disturbance where motile fauna were proportionally much more abundant than sessile (Fig. 6B).

Predator/scavengers were consistently the most abundant feeding group and deposit feeders the least abundant group in all disturbance regimes. The abundance of all feeding groups increased with reduced disturbance (Fig. 6C) and is all highest in the 100 to $150 \mathrm{~m}$ zone (Fig. 6D). The proportional abundance of each group did not change significantly with distance from disturbance except close to the source of disturbance where there was a reduced proportional abundance of sestonivores and increased proportional abundance of deposit feeders.

In the above, we have analysed disturbance separately in terms of both observed seabed disturbance and distance from disturbance source. The asymmetric distribution of drill cuttings (see Fig. 3) results in an 'imperfect' match between distance and apparent disturbance. We have therefore also examined community parameters for trends with disturbance within distance zones (Fig. 7). For simplicity, $50 \mathrm{~m}$ transect units were graded into more disturbed and less disturbed categories (see Fig. 7 legend) Total megafaunal abundance (Fig. 7A) in disturbed areas increased with distance from disturbance source; in the less disturbed areas, total abundance peaked at intermediate distances. The proportional abundance of motile fauna (Fig. 7B) was generally higher than sessile in disturbed areas, with highest proportional abundance of motile fauna at intermediate distances from disturbance. In undisturbed areas motile to sessile faunal proportional 

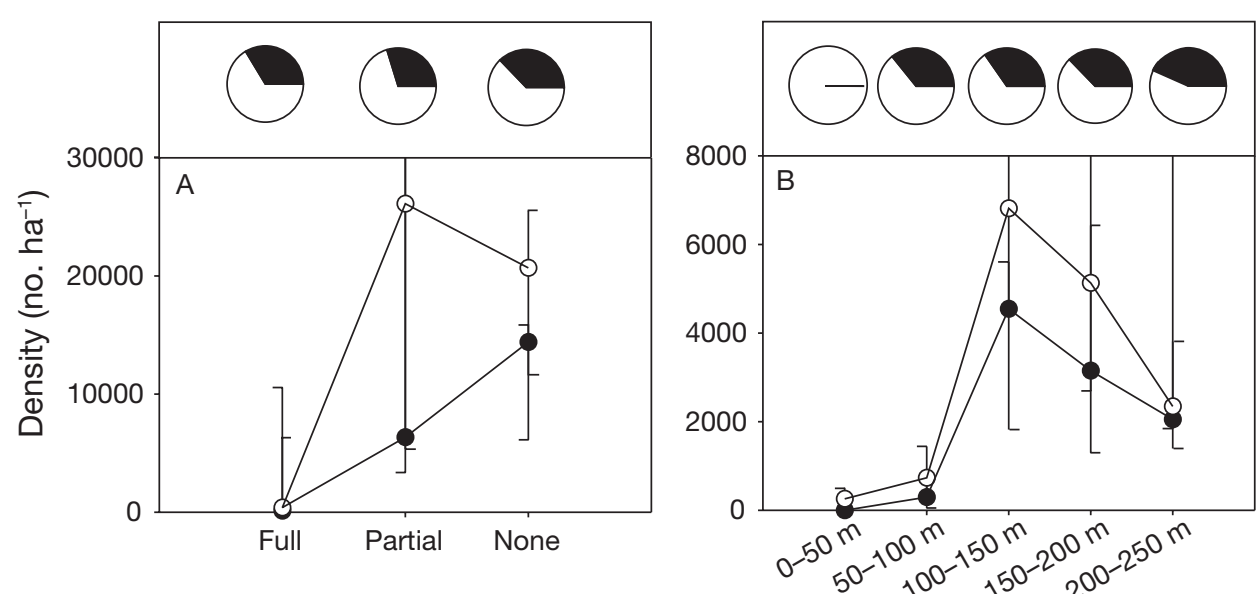

O Motile

- Sessile
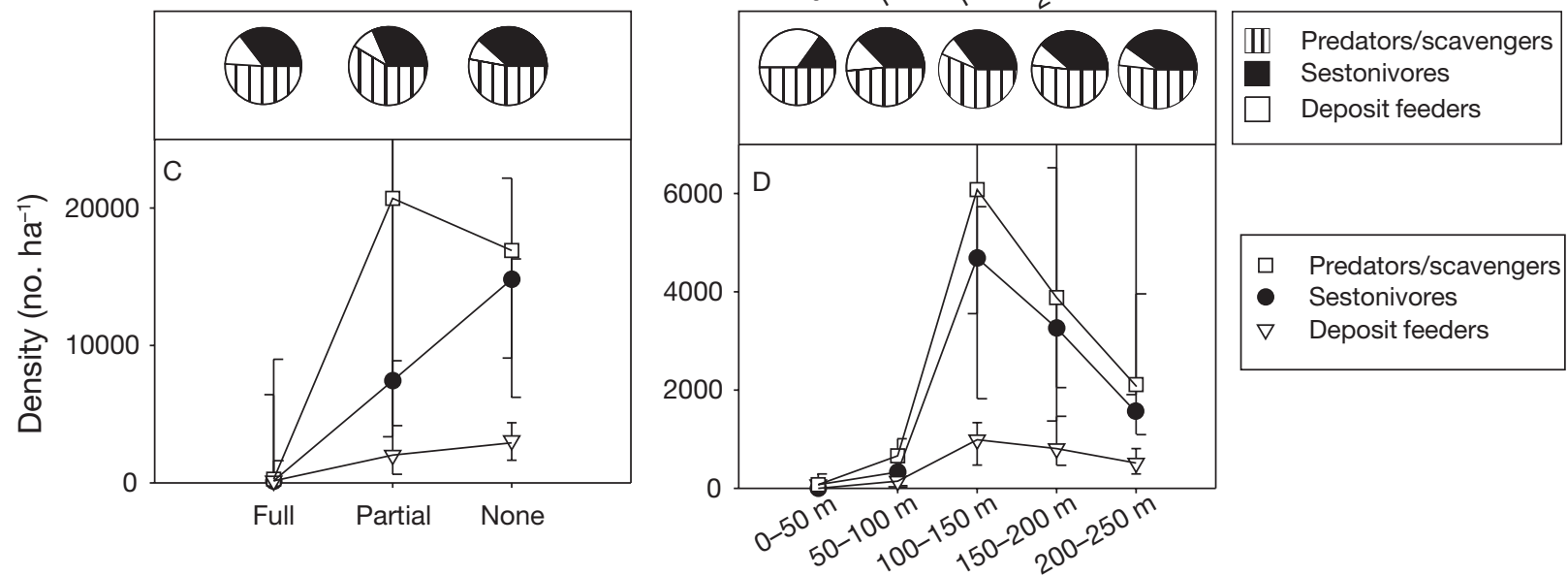

Fig. 6. Variations in the median abundance and composition of megafaunal functional groups around the Laggan site illustrating $(A, B)$ faunal motility and $(C, D)$ feeding mode in relation to $(A, C)$ disturbance level and $(B, D)$ distance from disturbance source. Error bars represent $95 \%$ confidence intervals calculated using a 1-sample sign test; pie charts show corresponding proportional abundance of functional groups

abundances reduced with distance from disturbance, to approximately equal abundances at 150 to $200 \mathrm{~m}$ from disturbance. Species richness (Fig. 7C) was consistently high in less disturbed areas; in more disturbed areas richness increased with distance. Species diversity measures have revealed significantly reduced diversity with proximity to disturbance source but, in the intermediate zones depicted (Fig. 7D), there is no significant change in $H^{\prime}$ with distance within the disturbed $(H=5.46, \mathrm{p}=0.07)$ or less disturbed areas $(H=6.98, \mathrm{p}=0.07)$.

\section{DISCUSSION}

\section{Effects of disturbance on megafaunal abundance}

Megafaunal abundance at Laggan was significantly reduced by disturbance. Megafaunal numbers were very low in disturbed areas and close to the disturbance source. As this study was completed within a month of the initial disturbance, this reflected the ini- tial disturbance of the communities by physical smothering and burial of organisms also observed in other studies (Stronkhorst et al. 2003). Highly motile organisms responded by moving away from the disturbance, as has been previously noted (e.g. Bluhm 2001), but for less motile taxa, motility was inversely proportional with mortality. Outside the area of complete disturbance megafaunal taxa responded differently to disturbance, likely a result of a complex interaction of factors including feeding mode, motility, particle removal rate and rate of sedimentation.

Predator/scavenger abundances increased dramatically in the disturbed zones at Laggan as a result of increased mortality of other taxa and potentially increased available food (i.e. carrion) as observed in shallow-water studies (Ramsay et al. 1998). There may have also been some enrichment effects, with recently exposed sub-surface sediments providing a food source for meio- and macro-faunal prey species.

The sestonivores increased in abundance with reduction in disturbance at Laggan. Survival of ses- 

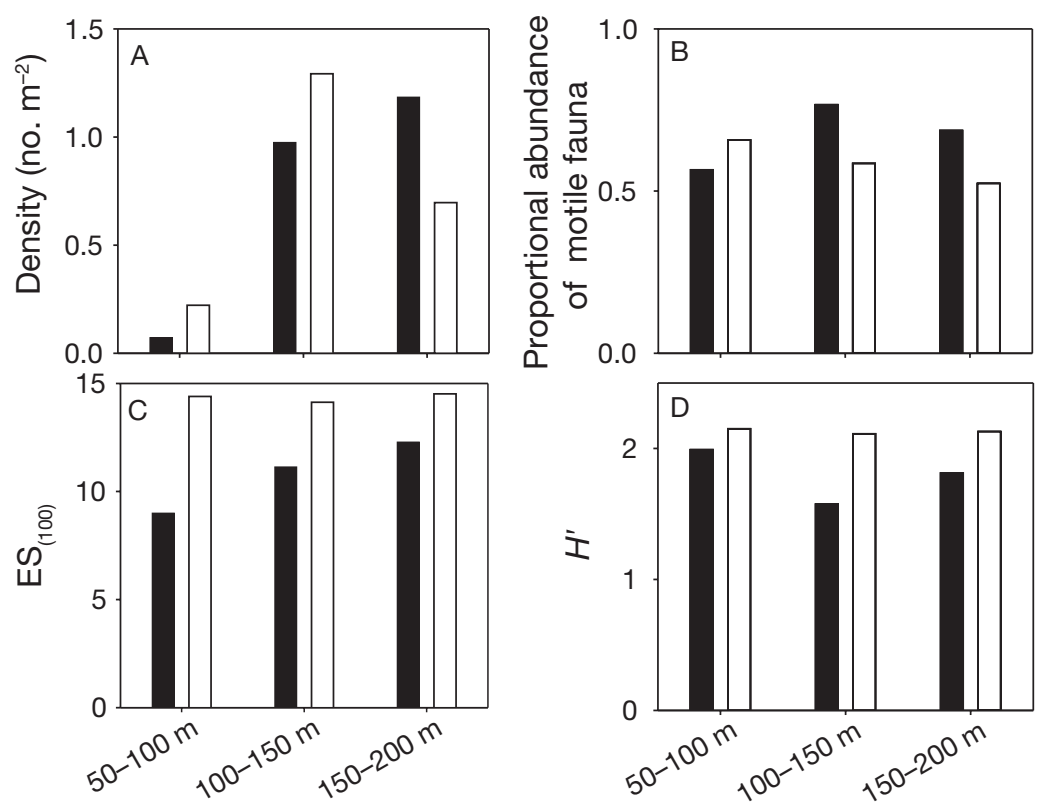

Fig. 7. Comparisons of megafaunal abundance and diversity in more (black bars) and less (white bars) disturbed areas within 3 distance zones around the Laggan site $\left(H^{\prime}\right.$, Shannon-Wiener index; $\mathrm{ES}_{(\mathrm{n})}$, rarefied species richness). At 50 to $100 \mathrm{~m}$ from the source of disturbance 'more disturbed' represents transect sections with $>50 \%$ complete disturbance $(\mathrm{n}=14)$; 'less disturbed' have $<50 \%$ complete disturbance $(\mathrm{n}=4)$. At 100 to 150 and 150 to $200 \mathrm{~m}$ 'more disturbed' represents transect sections with $<50 \%$ of no visible disturbance ( $\mathrm{n}=9$ and 8 , respectively); 'less disturbed' have $>50 \%$ no visible disturbance ( $\mathrm{n}=9$ and 10 , respectively)

tonivores at Laggan was shown to be directly related to motility. The impact of disturbance on sessile forms would be related directly to levels of suspended solids and to their ability to clear particles from their feeding and respiratory surfaces, as observed in many shallowwater sessile organisms (Rogers 1990). Disturbance may also have sub-lethal effects on megabenthic organisms, particularly sessile forms, which are not addressed in this study.

Deposit feeder abundance was not significantly different between partial and undisturbed areas at Laggan; these taxa are typically adapted to handling large amounts of particulate material and so may not be as susceptible to increased sedimentation. Deposit feeders, such as epibenthic echinoids and holothurians, are likely to be amongst the first recolonisers of the disturbed area. The increased availability of fine particles may reduce the need to sort through larger mixed-size sediment complexes (Hudson et al. 2004), potentially allowing greater turnover and increased reprocessing of organic material within disturbed areas. In undisturbed areas, deposit feeder abundance may be limited by high abundances of suspension feeders (Gray 1974). The reduction in suspension feeders resulting from disturbance, along with the changes to the substratum observed at Laggan, may have promoted the preferential recolonisation of impacted areas by epibenthic deposit feeders, thereby changing overall species composition and allowing deposit feeders to dominate the disturbance/ recolonisation community.

At Laggan faunal abundances increased with reductions in disturbance. In this study it is not known if abundances are at or near 'normal' levels; an indication of this can be gained from comparison with other, undisturbed ecosystems in similar physical environments (Fig. 8). The megafaunal communities of the Laggan area, although not arctic by location, essentially inhabit arctic waters from the Norwegian Sea, alternating between Norwegian Sea Arctic Intermediate Water and Faroe-Shetland Channel Bottom Water (Turrell et al. 1999). It is therefore more relevant to compare the Laggan communities with those of the Norwegian Sea and the Arctic rather than the geographically closer Rockall Trough. Abundances were compared with respect to depth, as it has been shown to have important controls on faunal abundances (Piepenburg et al. 2001). While megafaunal abundance at Laggan was variable in areas of no or limited disturbance (244 to 11514 ind. $\left.\mathrm{ha}^{-1}\right)$, it is towards the low end of values found in other undisturbed arctic megafaunal studies. In disturbed areas, faunal abundance was clearly reduced in comparison to other studies. These comparisons must be tentative as a result of physical differences between sites or methodological variation, particularly the inclusion of smaller faunal size classes in other studies. Nevertheless, the observed reductions in abundance with disturbance at Laggan suggest significant changes in ecosystem function.

\section{Effects of disturbance on megafaunal diversity}

Diversity increased with distance from the source of disturbance at Laggan. Some diversity indices showed a small decrease in diversity at maximal distance and minimal disturbance. Diversity was depressed by high disturbance but intermediate levels can increase diversity levels (e.g. Connell 1978). The trend observed at Laggan was very slight and may be attributed to reduced sampling effort at minimal disturbance sites. The whole community multivariate measures reflected a clear trend of increased similarity of megabenthic 

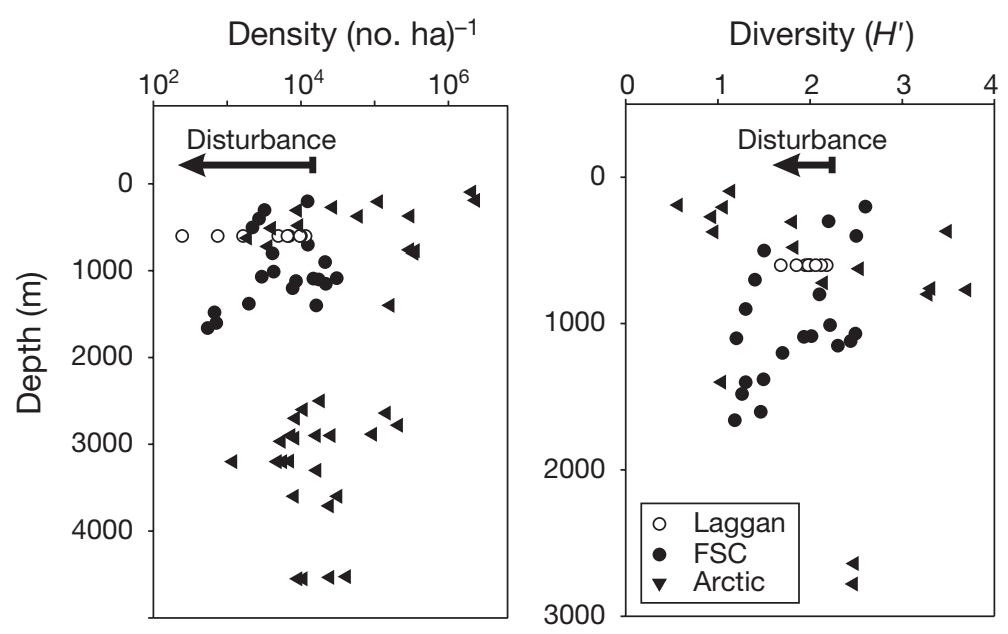

Fig. 8. Comparisons of megafaunal abundance and Shannon-Wiener diversity $\left(H^{\prime}\right)$ with depth for this study (o: Laggan site; increased disturbance is indicated with arrow), studies in the Faroe-Shetland Channel (FSC) (๑: Axelsson 2003, D. O. B. Jones unpubl. data) and other arctic studies («: Dahl et al. 1976, Christiansen \& Thiel 1992, Mayer \& Piepenburg 1996, Starmans et al.1999, Piepenburg et al. 2001)

communities with decreased disturbance. This trend is commonly observed in community measures in many marine disturbance settings (Clarke \& Warwick 2001).

The megafaunal diversity of Laggan, as with abundance, was variable with extent and degree of disturbance. The Shannon-Wiener diversity at Laggan was broadly similar to comparable studies of megafaunal diversity in undisturbed arctic areas (Fig. 8), although this should interpreted cautiously given the differences in sampling methodology between studies. Shannon-Wiener diversity in disturbed areas at Laggan was low, but within the values recorded at undisturbed sites elsewhere; this may result from the typically high dominance levels observed in many undisturbed arctic megafaunal studies (Starmans et al. 1999, Piepenburg et al. 2001). At Laggan, $H^{\prime}$ is driven by low richness and high evenness; unfortunately richness cannot readily be compared between studies (Gray 2000). The similarity of diversity at Laggan and in other arctic megafaunal communities suggests that the less disturbed ecosystems at Laggan have similar 'function' to those in comparable, undisturbed areas. Diversity is best used as a measure for ecosystem health in conjunction with information on the functioning of specific ecological aspects of the community (Loreau et al. 2002). Changes in diversity with initial disturbance may not adversely affect ecosystem functioning; in many cases a high diversity can act to buffer the effects of first disturbance. However, as species are displaced by disturbance it becomes increasingly likely that species dominating the functionality of an ecosystem will disappear (Hughes \& Petchey 2001). Suites of species responsible for specific functions may become smaller, thus increasing the susceptibility of the ecosystem to further disturbance. In the deep-water ecosystem at Laggan there appear to be only a few megafaunal species that are responsible for some major ecosystem functions, particularly those associated with processing of soft sediments. Disturbance may have impacted the ability of the Laggan ecosystem to utilise available resources as a result of differences in species resource use and the effects of interactions among species (Hughes \& Petchey 2001).

The relative changes in megafaunal diversity and abundance with physical anthropogenic disturbance recorded at Laggan are common to other areas despite differences in the community composition (Borowski \& Thiel 1998, Bluhm 2001). As an example, megafaunal communities at Laggan are significantly different from those at shallower depths in the Faroe-Shetland Channel (authors' pers. obs.) with virtually no megafaunal species common between Laggan $(600 \mathrm{~m})$ and shallower study sites $(508 \mathrm{~m})$ as a result of the large changes in water mass properties (particularly temperature) that occur between these depths in the Faroe-Shetland Channel. While diversity and abundance were higher in these shallower communities, both of these measures decreased in a similar way with disturbance.

\section{The nature of disturbance}

The extent of visible seabed disturbance at Laggan is relatively small in comparison with other studies of well sites (Davies et al. 1981, Olsgard \& Gray 1995) but larger than found at previous well locations in this area (Block 206/1, Anonymous 2004). The widespread effects on the fauna from drilling activity on the Norwegian continental shelf (Olsgard \& Gray 1995) did not appear to have occurred around Laggan. Many of these effects were attributed to the discharge of cuttings contaminated with oil-based drilling mud; in Laggan only water-based muds were discharged to the seabed (Anonymous 2004). Note, however, that comparisons with studies on macrofauna (e.g. Olsgard \& Gray 1995) should be treated with caution as only megafauna were analysed in the present study.

The effects of physical disturbance at Laggan were manifested as the partial or complete defaunation of disturbed patches through physical smothering and (presumed) direct mortality. Numerous additional effects of disturbance on sediment properties which 
may impact subsequent community recovery were observed. Changes to sediment topography were noted as a result of disturbance; such changes can alter near bed hydrodynamics and may therefore affect the deposition of particles, such as organic matter and benthic invertebrate larvae (Dernie et al. 2003). This may be particularly important in the high current regimes to the West of Shetland. Reduced sediment heterogeneity was apparent in the disturbed areas at Laggan; this leads to reduced diversity in the deep sea (Levin et al. 2001). The blanketing of the seabed with sediment of a different composition, such as occurred at Laggan, has been shown elsewhere to result in conditions unfavourable to the typical resident communities, reducing immigration of mobile fauna and limiting larval settlement (Snelgrove et al. 1999), and increasing recovery time. The increase in suspended particulate loading as a result of disturbance at Laggan may have lead to clogging of filter feeding apparatus of some organisms (Sharma et al. 2001).

At Laggan the most obvious environmental change with disturbance was a change from coarse to fine sediment. In studies of disturbance by trawling in shallow water, recovery was quickest in areas of coarse sediment (Thrush et al. 1995), but more stable, muddy areas recovered slowly (Tuck et al. 1998). Measured rates of recovery for mobile species from fishing disturbance were largely as a result of immigration, since what is known of life histories of benthic species (Brey 1999) suggested that population regeneration would not occur on these time scales.

Summarising, this study indicates that physical disturbance in deep-water areas can have significant impacts on megafaunal communities, reducing the abundance and diversity of fauna and modifying community composition. In the case of the present study of drilling impact, the areal extent of the main effects appears to be relatively small. This work suggests the utility of ROV systems for the high resolution investigation of deepwater impacts on megafaunal communities.

Acknowledgements. We thank TOTAL E\&P UK, Subsea 7 , Transocean and Fugro for their support. The work was carried out as part of the SERPENT and DIEPS (Deep-water Industry, Environment, Policy and Science) projects. We thank T. Horton, M. Thurston and P. Tyler (National Environment Research Council, NERC) for taxonomic assistance and L. Feighery (Fugro) for the hydrographic data. D.O.B.J. was funded by NERC studentship NER/S/A/2002/ 10397 and DIEPS grant NE/C508518/1.

\section{LITERATURE CITED}

Anonymous (2004) Laggan appraisal well 206/1a-ABC1 environmental statement. Statement prepared by TOTAL E\&P UK and AURORA Environmental. Total E\&P UK, Aberdeen
Axelsson M (2003) The deep seabed of the UK continental margin - integration and interpretation of geological and biological data. PhD thesis, University of Southampton

Bett BJ (2001) UK Atlantic Margin Environmental Survey: introduction and overview of bathyal benthic ecology. Cont Shelf Res 21:917-956

Bluhm H (2001) Re-establishment of an abyssal megabenthic community after experimental physical disturbance of the seafloor. Deep-Sea Res II 48:3841-3868

Bluhm H, Schriever G, Thiel H (1995) Megabenthic recolonization in an experimentally disturbed abyssal manganese nodule area. Mar Georesour Geotechnol 13: 393-416

Borowski C, Thiel H (1998) Deep-sea macrofaunal impacts of a large-scale physical disturbance experiment in the Southeast Pacific. Deep-Sea Res II 45:55-81

Brey $\mathrm{T}$ (1999) Growth performance and mortality in aquatic macrobenthic invertebrates. Adv Mar Biol 35:153-223

Bullough LW, Turrell WR, Buchan P, Priede IG (1998) Commercial deep water trawling at sub-zero temperatures observations from the Faroe-Shetland channel. Fish Res 39:33-41

Christiansen B, Thiel H (1992) Deep-sea epibenthic megafauna of the Northeast Atlantic: abundance and biomass at three mid-oceanic locations estimated from photographic transects. In: Rowe GT, Pariente V (eds) Deep sea food chains and the global carbon cycle. Kluwer Academic Publishers, Dordrecht, p 125-138

Clarke KR, Warwick RM (2001) Changes in marine communities: an approach to statistical analysis and interpretation. Plymouth Marine Laboratory, Plymouth

Colwell RK, Mao CX, Chang J (2004) Interpolating, extrapolating and comparing incidence-based species accumulation curves. Ecology 85:2717-2727

Connell JH (1978) Diversity in tropical rain forests and coral reefs. Science 199:1302-1310

Dahl E, Laubier L, Sibuet M, Stroemberg JO (1976) Some quantitative results on benthic communities of the deep Norwegian Sea. Astarte 9:61-79

Davies JM, Hardy R, McIntyre AD (1981) Environmental effects of North Sea oil operations. Mar Pollut Bull 12: 412-416

Davies JM, Kingston PF (1992) Sources of environmental disturbance associated with offshore oil and gas development. In: Cairns WJ (ed) North Sea oil and the environment-developing oil and gas resources, environmental impacts and resources. International Council on Oil and the Environment. Elsevier, London, p $417-440$

Dayton PK, Hessler RR (1972) Role of biological disturbance in maintaining diversity in the deep-sea. Deep-Sea Res 19: 199-208

Dernie KM, Kaiser MJ, Richardson EA, Warwick RM (2003) Recovery of soft sediment communities and habitats following physical disturbance. J Exp Mar Biol Ecol 285-286: 415-434

Emmerson MC, Solan M, Emes C, Paterson DM, Raffaelli D (2001) Consistent patterns and the idiosyncratic effects of biodiversity in marine ecosystems. Nature 411:73-77

Gotelli NJ, Colwell RK (2001) Quantifying biodiversity: procedures and pitfalls in the measurement and comparison of species richness. Ecol Lett 4:379-391

Gray JS (1974) Animal-sediment relationships. Oceanogr Mar Biol 12:223-261

Gray JS (2000) The measurement of marine species diversity, with an application to the benthic fauna of the Norwegian continental shelf. J Exp Mar Biol Ecol 250:23-49 
Hudson IR, Wigham BD, Tyler PA (2004) The feeding behaviour of a deep-sea holothurian, Stichopus tremulus (Gunnerus) based on in situ observations and experiments using a Remotely Operated Vehicle. J Exp Mar Biol Ecol 301:75-91

Hughes JB, Petchey OL (2001) Merging perspectives on biodiversity and ecosystem functioning. Trends Ecol Evol 16: 222-223

Levin LA, Etter RJ, Rex MA, Gooday AJ and 5 others (2001) Environmental influences on regional deep-sea species diversity. Annu Rev Ecol Syst 32:51-93

Loreau M, Naeem S, Inchausti P (2002) Biodiversity and ecosystem functioning. Oxford University Press, Oxford

Magurran AE (2003) Measuring biological diversity. Blackwell Science, Oxford

Mayer M, Piepenburg D (1996) Epibenthic community patterns on the continental slope off East Greenland at $75^{\circ} \mathrm{N}$. Mar Ecol Prog Ser 143:151-164

Narayanaswamy BE, Bett BJ, Gage JD (2005) Ecology of bathyal polychaete fauna at an Arctic-Atlantic boundary (Faroe-Shetland Channel, North-east Atlantic). Mar Biol Res 1:20-32

Olsgard F, Gray JS (1995) A comprehensive analysis of the effects of offshore oil and gas exploration and production on the benthic communities of the Norwegian continental shelf. Mar Ecol Prog Ser 122:277-306

Piepenburg D, Chernova NV, Dorrien C, Gutt J, Neyelov AV, Rachor E, Saldanha L, Schmid MK (1996) Megabenthic communities in the waters around Svalbard. Polar Biol 16: 431-446

Piepenburg D, Brandt A, Juterzenka Kv, Mayer M, Schnack K, Seiler D, Witte U, Spindler M (2001) Patterns and determinants of the distribution and structure of benthic faunal assemblages in the northern north Atlantic. In: Schafer P, Ritzrau M, Schluter M, Thiede J (eds) The northern North Atlantic: a changing environment. Springer, Berlin, p 179-198

Ramsay K, Kaiser MJ, Hughes RN (1998) Responses of benthic scavengers to fishing disturbance by towed gears in different habitats. J Exp Mar Biol Ecol 224:73-89

Rogers CS (1990) Reponses of coral reefs and reef organisms to sedimentation. Mar Ecol Prog Ser 62:185-202

Romero-Wetzel MB, Gerlach S (1991) Abundance, biomass, size distribution and bioturbation potential of deep-sea macrozoobenthos on the Voring Plateau (1200-1500 m, Norwegian Sea). Meeresforsch 33:247-265

Schwinghamer P (1981) Characteristic size distribution of integral benthic communities. Can J Fish Aquat Sci 38: $1255-1263$

Editorial responsibility: Otto Kinne (Editor-in-Chief), Oldendorf/Luhe, Germany
Sharma R, Nath BN, Parthiban G, Sankar SJ (2001) Sediment redistribution during simulated benthic disturbance and its implications on deep seabed mining. Deep-Sea Res II 48:3363-3380

Smith KL Jr, Kaufmann RS, Wakefield WW (1993) Mobile megafaunal activity monitored with a time-lapse camera in the abyssal North Pacific. Deep-Sea Res I 40:2307-2324

Snelgrove PVR, Grassle JP, Grassle JF, Petrecca RF, Ma HG (1999) In situ habitat selection by settling larvae of marine soft-sediment invertebrates. Limnol Oceanogr 44: 1341-1347

Solan M, Germano JD, Rhoads DC, Smith C and 6 others (2002) Towards a greater understanding of pattern, scale and process in marine benthic systems: a picture is worth a thousand worms. J Exp Mar Biol Ecol 285-286:313-338

Solan M, Cardinale BJ, Downing AL, Engelhardt KAM, Ruesink JL, Srivastava DS (2004) Extinction and ecosystem function in the marine benthos. Science 306: $1177-1180$

Sousa WP (1984) The role of disturbance in natural communities. Annu Rev Ecol Syst 15:353-391

Starmans A, Gutt J, Arntz WE (1999) Mega-epibenthic communities in Arctic and Antarctic shelf areas. Mar Biol 135: $269-280$

Stride AH (1982) Offshore tidal sands: processes and deposits. Chapman \& Hall, London

Stronkhorst J, Ariese F, Van Hattum B, Postma JF and 6 others (2003) Environmental impact and recovery at two dumping sites for dredged material in the North Sea. Environ Pollut 124:17-31

Thomson CW (1873) The depths of the sea. MacMillan, London

Thrush SF, Hewitt JE, Cummings VJ, Dayton PK (1995) The impact of scallop dredging on marine benthic communities: what can be predicted from the results of experiments? Mar Ecol Prog Ser 129:141-150

Tuck I, Hall SJ, Robertson M, Armstrong E, Basford D (1998) Effects of physical trawling disturbance in a previously unfished sheltered Scottish sea loch. Mar Ecol Prog Ser 162:227-242

Turrell WR, Slesser G, Adams RD, Payne R, Gillibrand PA (1999) Decadal variability in the composition of Faroe Shetland Channel bottom water. Deep-Sea Res I 46:1-25

Underwood AJ (1994) On beyond BACI - sampling designs that might reliably detect environmental disturbances. Ecol Appl 4:3-15

Walker M, Tyler PA, Billett DSM (1987) Organic and calorific content of the body tissues of deep sea elasipodid holothurians in the northeast Atlantic Ocean. Mar Biol 96:277-282

Submitted: July 15, 2005; Accepted: December 8, 2005

Proofs received from author(s): July 28, 2006 